Ethos : Jurnal Penelitian dan Pengabdian kepada Masyarakat, Vol 7, No.1, Januari 2019: 129-136

PKM

\title{
Peningkatan Ekonomi Petani Rumput Laut Melalui Program Diversifikasi Produk Olahan Rumput laut (Diporla) Di Kelurahan Pantai Amal KeCAMATAN TARAKan Timur Kota TARAKan KaLIMANTAN UTARA
}

\author{
${ }^{1}$ Alfi Suciyati, ${ }^{2}$ Ratna Yulinda, ${ }^{3}$ Nursia \\ ${ }^{1,3}$ Fakultas Keguruan dan Ilmu Pendidikan, Universitas Borneo Tarakan \\ ${ }^{2}$ Fakultas Keguruan dan Ilmu Pendidikan, Universitas Lambung Mangkurat \\ E-mail: 1alphie120115@gmail.com
}

\begin{abstract}
Abstrack. Eucheuma Cottonii is one of the local potentials of Tarakan City which plays an important role in the economy of the community. The problem often encountered on the ground is the selling price of unstable seaweed. Seaweed is also limited to being sold in the form of dried seaweed. The solution that can be implemented immediately is the Diversified Process of Seaweed Products (DIPORLA). Eucheuma Cottoni can be processed into various processed foods. The DIPORLA program aims to assist seaweed farmers through two aspects, namely the production aspect, and business management and marketing aspects. The method of implementing the DIPORLA program is through workshops and mentoring. Assistance is carried out starting from equipment preparation, production, packaging, marketing, business management, to business evaluation. Through the DIPORLA program, it is expected that the economic value of seaweed can increase and the income of seaweed farmers can be more feasible. The implementation of the DIPORLA program was able to show improvement in several respects, namely: 1) enhancing the ability of partners, including the ability to process seaweed by $75 \%$, the ability to package, and market products, each by 50\%, business management capabilities and business evaluation of each by 50\%, and 2) an increase in income of seaweed farmers seen from the acquisition of turnover which increased by $249.2 \%$ for four months (July to October 2018). There are five types of products produced in this program, namely Nori Chips, Seaweed Cheese Cake, Seaweed Brownies, Seaweed Candy, and Seaweed Candied. Gradually, sales turnover has increased from month to month
\end{abstract}

Keywords: Seaweed, Eucheuma cottonii, Seaweed product diversification.

\begin{abstract}
Abstrak. Rumput Laut jenis Eucheuma Cottonii merupakan salah satu potensi lokal Kota Tarakan yang berperan penting dalam perekonomian masyarakat. Permasalahan yang sering ditemui di lapangan adalah harga jual rumput laut yang tidak stabil. Rumput laut juga masih sebatas dijual dalam bentuk rumput laut kering. Solusi yang dapat segera dilaksanakan adalah dengan Program Diversifikasi Produk Olahan Rumput Laut (DIPORLA). Rumput laut jenis Eucheuma Cottoni dapat diolah menjadi berbagai olahan makanan. Program DIPORLA bertujuan membantu petani rumput laut melalui dua aspek, yaitu aspek produksi, dan aspek manajemen usaha dan pemasaran. Metode pelaksanaan program DIPORLA yaitu melalui workshop dan pendampingan. Pendampingan dilakukan mulai dari penyiapan peralatan, produksi, pengemasan, pemasaran, manajemen usaha, hingga evaluasi usaha. Melalui program DIPORLA diharapkan nilai ekonomi rumput laut dapat meningkat dan pendapatan masyarakat petani rumput laut dapat lebih layak. Pelaksanaan program DIPORLA mampu memperlihatkan peningkatan dalam beberapa hal, yaitu: 1) peningkatan kemampuan mitra, meliputi kemampuan mengolah rumput laut sebesar 75\%, kemampuan mengemas, dan memasarkan produk, masing-masing
\end{abstract}


sebesar 50\%, kemampuan manajemen usaha dan evaluasi usaha masing-masing sebesar 50\%, dan 2) peningkatan pendapatan petani rumput laut dilihat dari perolehan omset yang mengalami peningkatan sebesar 249,2\% selama empat bulan (Juli hingga Oktober 2018). Produk yang dihasilkan dalam program ini ada lima macam, yaitu Nori Chips, Cheese Cake Rumput Laut, Brownies Rumput Laut, Permen Rumput Laut, dan Manisan Rumput Laut

Kata kunci: Rumput laut, Eucheuma cottonii, Diversifikasi produk rumput laut.

\section{Pendahuluan}

Rumput laut tetap merupakan sumber daya yang relatif belum tergarap dengan potensi besar sebagai bahan makanan kaya nutrisi, bahan pakan, kosmetik, agrichemical, biomaterial dan molekul bioenergy (Chopin, 2012). Rumput Laut jenis Eucheuma cottonii merupakan salah satu potensi lokal Kota Tarakan yang berperan penting dalam perekonomian masyarakat. Permasalahan yang sering ditemui di lapangan (kawasan Kelurahan Pantai Amal, Tarakan) adalah cuaca yang tidak menentu sehingga mengurangi hasil panen, juga harga jual rumput laut yang tidak stabil. Rumput laut juga masih sebatas dijual dalam bentuk rumput laut kering. Hasil studi yang dilakukan oleh Imam (2016) menyimpulkan bahwa rantai pemasaran yang panjang akibat belum adanya KUD ataupun perusahaan lokal (di Tarakan) membuat para pengumpul menekan harga rumput laut. Selain itu juga akibat kurangnya permintaan dari perusahaan domestik sehingga pengumpul lokal menekan harga rumput laut. Hikmah (2015) menyebutkan bahwa saat ini sekitar $80 \%$ rumput laut Indonesia hanya diekspor sebagai bahan baku primer (raw material) dalam bentuk rumput laut kering dengan harga relatif rendah, dan hanya $20 \%$ saja yang diolah di dalam negeri. Hal ini menyebabkan nilai tambah yang dihasilkan oleh produk rumput laut cenderung minim.

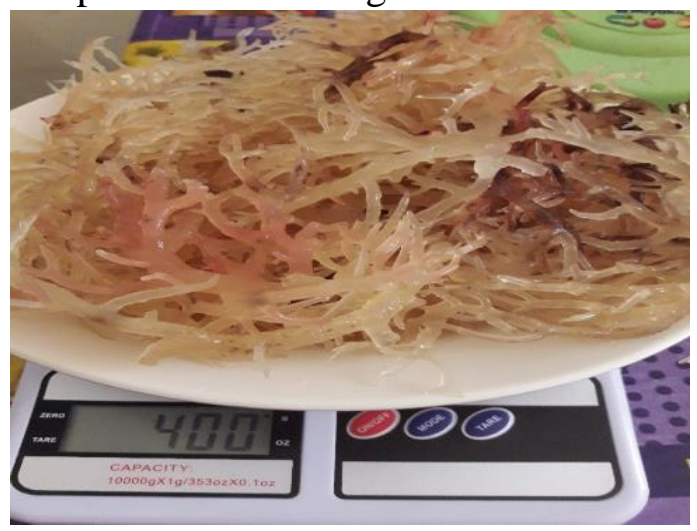

Gambar 1. Rumput laut Eucheuma cottonii

Kondisi tersebut di atas memerlukan perhatian dari berbagai pihak, khususnya Universitas Borneo Tarakan sebagai wujud pengabdian masyarakat. Solusi yang dapat segera dilaksanakan adalah dengan Program Diversifikasi Produk Olahan Rumput Laut (DIPORLA). Rumput laut yang dihasilkan di Kota Tarakan adalah jenis Eucheuma cottoni. Rumput laut jenis ini dapat diolah menjadi berbagai produk lain salah satunya adalah berbagai olahan makanan. Jenis rumput laut yang biasanya diolah menjadi makanan yang siap dikosumsi adalah jenis Eucheuma $s p$ dan Gellidium sp (Lubis, 2013). Rumput laut jenis Cottonii per 100 gram mengandung protein $0,7 \%$, lemak $0,2 \%$, air $3,4 \%$, serat pangan tidak larut 58,6 $\mathrm{g} / 100 \mathrm{~g}$, serat pangan larut $10,7 \mathrm{~g} / 100 \mathrm{~g}$. Selain itu, rumput laut tersebut mengandung sejumlah mineral yang 
dibutuhkan tubuh diantaranya kalsium (Ca) 2,8 mg/g, garam natrium (Na) 11,93 $\mathrm{mg} / \mathrm{g}$, kalium (K) 87,1 mg/g, magnesium (Mg) 2,88 mg/g dan seng (Zn) 0,01 mg/g (Santoso dalam Peranginangin et al., 2013).

Kelompok petani rumput laut di Kelurahan Pantai Amal Kota Tarakan, salah satunya kelompok Fajar Mentari yang diketuai oleh Ibu Juahidah sedang memulai usaha kecil makanan olahan rumput laut berupa kue, stik rumput laut dan permen rumput laut. Mereka belum produktif karena rintisan usaha ini masih terkendala berbagai hal, diantaranya teknik pengolahan belum maksimal, pengemasan masih kurang menarik, belum ada izin PIRT, tempat produksi belum memenuhi syarat, peralatan tidak lengkap, dan lain-lain. Hal ini membuat produksi olahan rumput laut tidak tertangani dengan baik. Untuk membantu kelompok-kelompok masyarakat petani rumput laut di Kelurahan Pantai Amal, Kecamatan Tarakan Timur yang berkeinginan kuat untuk berwirausaha produksi olahan rumput laut, diperlukan pendampingan dan bantuan berbagai hal. Melalui program Diversifikasi Produk Olahan Rumput Laut (DIPORLA) diharapkan nilai ekonomi rumput laut dapat meningkat dan pendapatan masyarakat petani rumput laut dapat lebih layak.

Dari beberapa persoalan yang telah dipaparkan di atas, inti yang menjadi persoalan prioritas mitra dan akan diselesaikan selama pelaksanaan program yaitu:

Tabel 1. Permasalahan Mitra

\begin{tabular}{ll}
\hline \multicolumn{1}{c}{ Aspek } & \multicolumn{1}{c}{ Permasalahan yang disepakati untuk diselesaikan } \\
\hline Aspek & 1. Mitra telah berusaha untuk menghasilkan produk olahan rumput laut \\
berupa kue dan stik rumput laut, namun hasil produksinya kurang \\
berkualitas, kurang menarik untuk dijual, dan belum ada variasi \\
produk lain.
\end{tabular}

Potensi yang mendukung usaha produk olahan rumput laut yang dilakukan oleh mitra antara lain:

1. Sumber daya rumput laut yang melimpah.

2. Bahan-bahan lain untuk pembuatan produk olahan rumput laut relatif mudah diperoleh.
3. Modal usaha pengolahan rumput laut menjadi berbagai produk makanan relatif tidak terlalu besar sehingga terjangkau oleh petani rumput laut.

4. Mitra sudah mencoba untuk menghasilkan produk, hal ini membuktikan bahwa mitra berkeinginan kuat untuk 
berwirausaha produk olahan rumput laut.

5. Lokasi mitra sangat dekat dengan Universitas Borneo Tarakan, sehingga pendampingan dalam Program DIPORLA dapat lebih intensif.

\section{Metode Penelitian}

Kirby (2003) menyatakan bahwa usaha kecil menengah memiliki beberapa masalah dalam pertumbuhannya. Masalah tersebut disebabkan kurangnya nilai-nilai entrepreneur, pembiayaan, dan pasar. Faktor-faktor eksternal lainnya seperti lingkungan makroekonomi, kebijakan dan peraturan pemerintah, dan ketersediaan prasarana fisik juga mempengaruhi pertumbuhan. Berdasar pendapat Kirby tersebut dapat diartikan bahwa untuk keberhasilan program
DIPORLA, perlu diperhatikan bagaimana menumbuhkan nilai-nilai enterpreneur, pembiayaan usaha, memperluas pemasaran, dan ketersediaan sarana prasarana fisik.

Dalam program DIPORLA, kelompok mitra yang berasal dari petani rumput laut diajarkan bagaimana melakukan diversifikasi pengolahan rumput laut yaitu dengan pembuatan berbagai olahan makanan berbahan rumput laut. Selain itu, mitra juga diajarkan konsep pengemasan produk yang menarik. Selanjutnya mitra akan dibantu dan didampingi agar dapat memiliki tempat dan peralatan yang memadahi, izin PIRT, pemasaran yang baik serta pembuatan bussiness plan untuk pengembangan usaha selanjutnya. Secara rinci, metode pelaksanaan program Diversifikasi Produk Olahan Rumput Laut (DIPORLA) adalah sebagai berikut:

Tabel 2. Metode Pelaksanaan Program DIPORLA

\begin{tabular}{lll}
\hline \multicolumn{1}{c}{ Bidang } & & \multicolumn{1}{c}{ Metode/Pendekatan/Langkah-langkah } \\
\hline Produksi & 1 & $\begin{array}{l}\text { Penataan tempat produksi, penyiapan peralatan dan identifikasi peralatan } \\
\text { utama yang belum dimiliki }\end{array}$ \\
& 2 & $\begin{array}{l}\text { Pelaksanaan Workshop Diversifikasi Pengolahan Rumput Laut (DIPORLA) } \\
\text { sekaligus penyerahan peralatan tambahan }\end{array}$ \\
& 4 & Pendampingan produksi hingga mitra dapat menghasilkan produk berkualitas \\
& 5 & Perancangan dan Pembuatan kemasan produk \\
Manajemen & 1 & Pembagian tugas dalam kelompok mitra maupun antarkelompok mitra \\
& 2 & Pendampingan Pengurusan izin PIRT \\
Pemasaran & 3 & Penyusunan business plan \\
& 1 & Pembuatan media/sarana promosi (akun media sosial, brosur/leaflet, spanduk) \\
& 2 & Pendampingan Proses Pemasaran \\
Evaluasi & 1 & Uji organoleptik dengan uji coba sampel produk dan angket respon produk ke \\
Program & & dosen/staf dan mahasiswa Universitas Borneo Tarakan \\
DIPORLA & 2 & $\begin{array}{l}\text { Perhitungan target penjualan } \\
\text { Perhitungan profit penjualan }\end{array}$ \\
& 3 & $\begin{array}{l}\text { Perhan } \\
\text { Pentuan langkah keberlanjutan program berdasar hasil evaluasi bersama }\end{array}$ \\
\hline
\end{tabular}




\section{Hasil Dan Pembahasan}

\section{Aspek Produksi}

Kegiatan DIPORLA diawali penataan tempat produksi, penyiapan peralatan dan identifikasi peralatan utama yang belum dimiliki oleh mitra. Penataan tempat produksi dimaksudkan untuk memberikan semangat yang baik untuk memulai produksi, sekaligus mendata apa saja peralatan produksi yang telah dimiliki. Kegiatan dilanjutkan dengan workshop DIPORLA (Gambar 2). Dalam workshop tersebut, mitra diajarkan beberapa cara pengolahan rumput laut dan pengemasannya. Beberapa produk yang sebelumnya sudah dihasilkan oleh mitra hanya perlu penyempurnaan dalam rasa, penampilan, dan pengemasan. Kegiatan workshop dilanjutkan dengan pendampingan produksi dan pengemasan (Gambar 3 dan 4). Dalam kegiatan pendampingan tersebut sekaligus diserahkan peralatanperalatan pokok yang belum dimiliki oleh mitra, seperti oven, blender, food processor, penggiling adonan, loyang, dan lain-lain. Pendampingan dilakukan selama kurang lebih lima bulan.

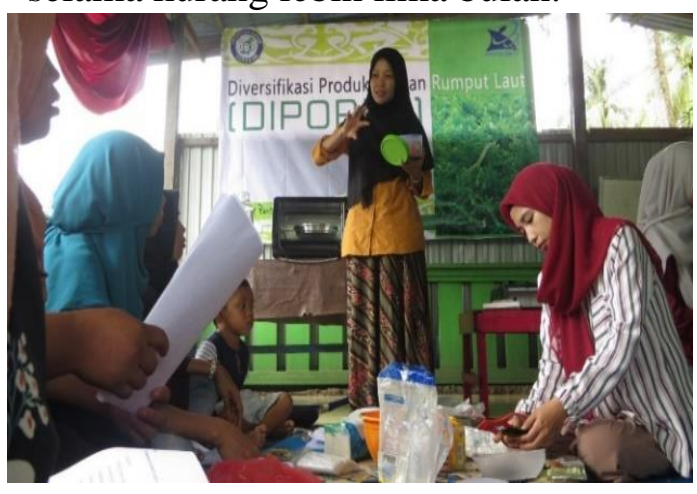

Gambar 2. Workshop Diversifikasi Produk Olahan Rumput Laut (DIPORLA)
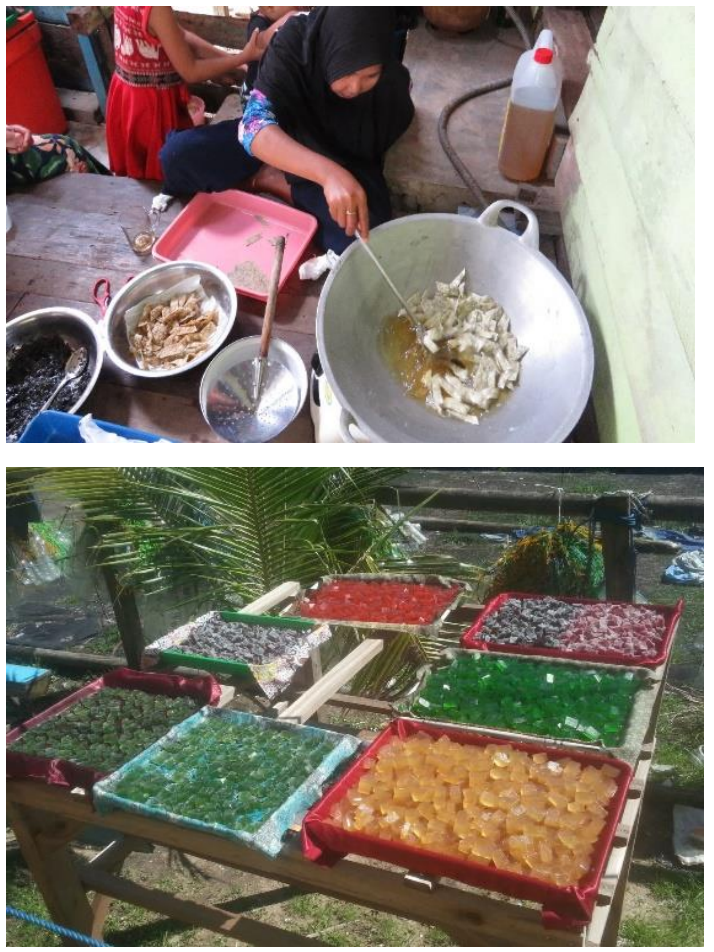

Gambar 3. Proses pembuatan Nori Chips dan Permen Rumput Laut yang dilakukan oleh mitra
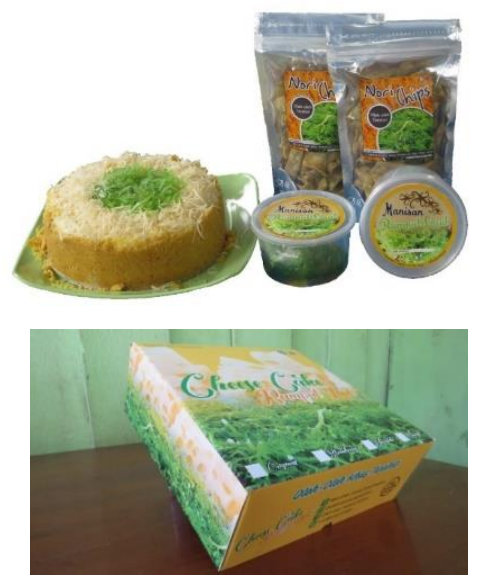

Gambar 4. Beberapa produk yang dihasilkan dalam program DIPORLA

Terdapat lima jenis produk yang diproduksi oleh peserta program, yaitu Nori Chips, Cheese Cake Rumput Laut, Brownies Rumput Laut, Permen Rumput Laut, dan Manisan Rumput Laut. Nori Chips, Cheese Cake dan Manisan Rumput Laut adalah produk baru, 
sedangkan Brownies dan Permen Rumput Laut sudah diproduksi sebelumnya, namun belum maksimal. Salah satu produk unggulan dalam program ini yaitu Nori Chips (Gambar 5). Snack rumput laut ini terbuat dari lembaran nori (rumput laut kering) yang diolah menjadi chips atau keripik. Nori Chips adalah produk yang mudah dalam pembuatannya, tahan lama, keuntungan per kemasan cukup tinggi, dan jumlah permintaannya cenderung lebih banyak dari produk lainnya.
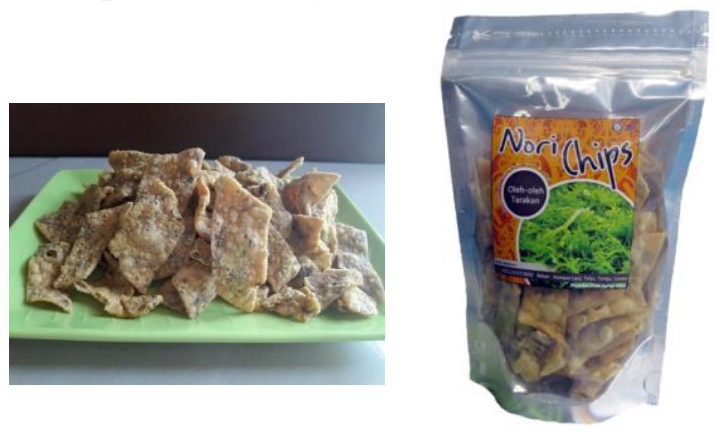

Gambar 5. Produk Nori Chips

Beberapa mahasiswa terlibat dalam kegiatan workshop dan pendampingan ini. Mahasiswa turut membantu menyiapkan jalannya workshop dan mendampingi mitra. Pembuatan desain kemasan, stiker kemasan, dan spanduk produk juga dibantu oleh mahasiswa. Pendampingan aspek produksi dilakukan hingga mitra dapat memproduksi dan mengemas produk secara baik dan mandiri.

\section{Aspek manajemen dan pemasaran}

Pada aspek manajemen dan pemasaran, mitra didampingi dalam pembuatan bussiness plan dan pengaturan pembagian tugas dalam kelompok. Selain itu, mitra juga didampingi dalam pengurusan Perizinan Pangan Industri Rumah Tangga (P-IRT). Perizinan ini sangat penting untuk keamanan pangan, legalitas, dan kemudahan pemasaran. Untuk dapat memasarkan produk secara lebih luas, produk pangan harus memiliki P-IRT. Peraturan Kepala Badan Pengawas Obat dan Makanan Republik Indonesia Nomor HK.03.1.23.04.12.2205 Tahun 2012 Tentang Pedoman Pemberian Sertifikat Produksi Pangan Industri Rumah Tangga menyebutkan bahwa Sertifikat Produksi Pangan Industri Rumah Tangga, yang selanjutnya disingkat SPP-IRT, adalah jaminan tertulis yang diberikan oleh Bupati/Walikota terhadap pangan produksi IRTP di wilayah kerjanya yang telah memenuhi persyaratan pemberian SPP-IRT dalam rangka peredaran Pangan Produksi Industri Rumah Tangga Pangan (IRTP).

Pada awalnya, pemasaran produk hanya sebatas kepada tetangga dan teman-teman terdekat. Melalui program DIPORLA, mitra dapat memasarkan produk secara lebih luas, baik melalui brosur, spanduk, maupun media sosial. Penggunaan media sosial sangat membantu kegiatan pemasaran ini. Dengan dikenalnya produk-produk yang dihasilkan dalam program ini, mitra pun mendapat kesempatan diundang dalam beberapa kegiatan bazaar dan kegiatan UMKM lain yang diselenggarakan oleh beberapa untuk mengenalkan produkproduk hasil program DIPORLA.

\section{Evaluasi Program DIPORLA}

Selama pendampingan berlangsung, diadakan evaluasi terutama terkait perbaikan kualitas produk, pemasaran, dan hasil penjualan. Melalui serangkaian uji organoleptik, diperoleh data rasa dan kualitas yang diminati oleh responden sehingga dilakukan perbaikan-perbaikan berdasar hasil uji tersebut. 
Kemampuan mitra sebelum dan selama mengikuti program DIPORLA diukur untuk mengetahui peningkatan yang diperoleh. Gambar 6 berikut ini memperlihatkan peningkatan yang diperoleh mitra.

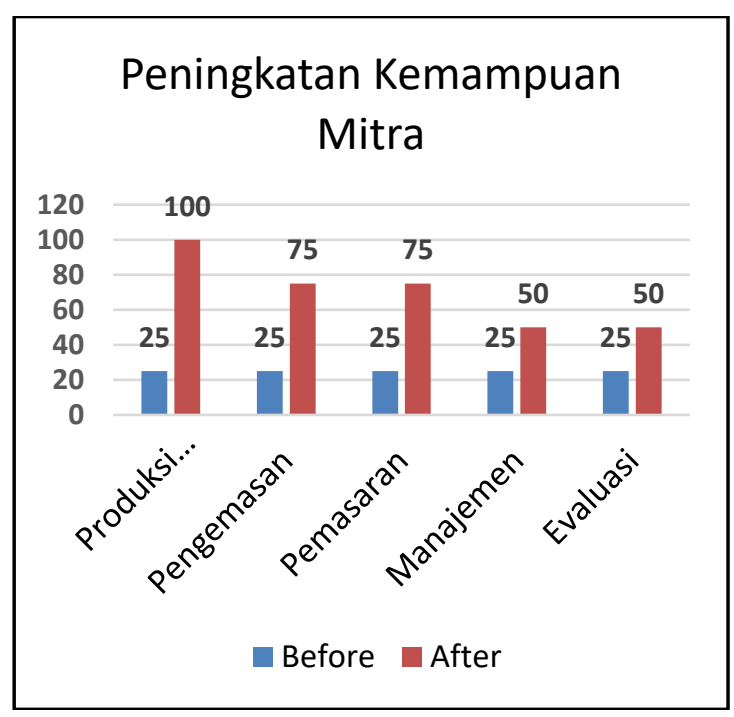

Gambar 6. Peningkatan kemampuan mitra sebelum dan sesudah program DIPORLA

Evaluasi pemasaran dilakukan dengan melakukan pencatatan dan penghitungan omset dan laba tiap bulan. Gambar 7 berikut memperlihatkan perolehan omset selama empat bulan (Juli sampai dengan November 2018).

Sebagai sebuah usaha atau bisnis yang baru mulai dirintis, omset penjualan tentunya masih sangat kecil. Akan tetapi mitra terus didampingi agar tetap bersemangat untuk memasarkan produk. Secara bertahap, omset penjualan mengalami peningkatan dari bulan ke bulan. Dari bulan Juli hingga November (empat bulan), peningkatan omset mengalami peningkatan sebesar 249,2 \%. Dengan perbaikan pemasaran, perbaikan kualitas produk, dan perbaikan manajemen secara terus menerus, diharapkan penjualan akan terus meningkat.

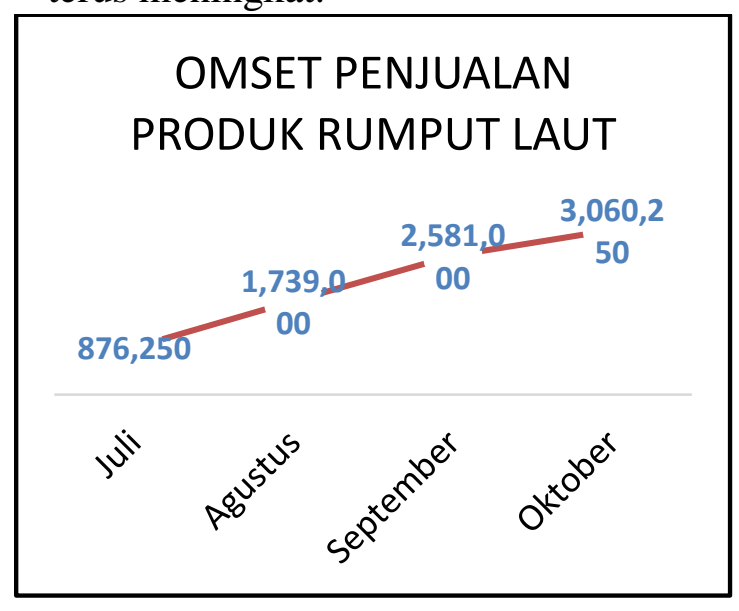

Gambar 7. Grafik perolehan omset mitra selama bulan Juli hingga November 2018

\section{Ucapan Terimakasih}

Ucapan Terimakasih disampaikan kepada Direktorat Riset dan Pengabdian Kepada Masyarakat (DRPM) Kementrian Riset, Teknologi, dan Pendidikan Tinggi yang telah mendanai program Pengabdian Kepada Masyarakat ini. Terimakasih juga disampaikan untuk Lembaga Penelitian dan Pengabdian Kepada Masyarakat (LPPM) Universitas Borneo Tarakan yang telah memfasilitasi sehingga kegiatan ini dapat berjalan dengan baik.

\section{Kesimpulan}

Kesimpulan yang dapat diperoleh dari pelaksanaan program Diversifikasi Pengolahan Rumput Laut (DIPORLA) yaitu:

1. Program DIPORLA mampu meningkatkan kemampuan mitra dalam aspek produksi, pengemasan, pemasaran, manajemen, dan evaluasi usaha. 
2. Program DIPORLA mampu meningkatkan pendapatan petani rumput laut.

\section{Daftar Pustaka}

Chopin, Thiery. Dr. 2012. Seaweed Aquaculture Provides Diversified Products, Key Ecosystem Functions. Global Aquaculture Advocate. Canada: University of New Brunswick.

Hikmah. 2015. Strategi Pengembangan Industri Pengolahan Komoditas Rumput Laut E. Cotonii Untuk Peningkatan Nilai Tambah di Sentra Kawasan Industrialisasi. J. Kebijakan Sosek KP Vol. 5 No. 1 Tahun 2015.

Imam, Muhammad. 2016. Studi Tentang

Pemberdayaan Masyarakat Petani Rumput laut di Kelurahan Pantai Amal Kecamatan Tarakan Timur
Kota Tarakan. eJournal Ilmu Pemerintahan, 4 (1), 2016: 64-77. ISSN 2477-2458, ejournal.ip.fisipunmul.ac.id

Kirby, David A. 2003. Entrepreneurship. London: McGraw Hill.

Lubis Yanti Meldasari, dkk. 2013. Pengaruh Konsentrasi Rumput Laut (Eucheuma Cottonii) dan Jenis Tepung pada Pembuatan Mie Basah. Jurnal Rona Teknik Pertanian Vol. 6 No. 1 April 2013.

Peranginangin R, Sinurat E, dan Darmawam M. 2013. Memproduksi Karaginan dari Rumput Laut. Jakarta: Penebar Swadaya.

Peraturan Kepala Badan Pengawas Obat dan Makanan Republik Indonesia Nomor HK.03.1.23.04.12.2205

Tahun 2012 Tentang Pedoman Pemberian Sertifikat Produksi Pangan Industri Rumah Tangga 